\title{
Analysis of Wholesome Elements and Heavy Metals in Red Soybean by Inductively Coupled Plasma Mass Spectrometry
}

\author{
Hui Li, Xia Lei, Hongchang Li, Yunchu Hu, Ruizhi Wen* \\ School of Sciences, Central South University of Forestry \& Technology, Changsha, China \\ Email: *csuft_wrz@126.com
}

How to cite this paper: $\mathrm{Li}, \mathrm{H}$., Lei, $\mathrm{X}$., Li, H.C., Hu, Y.C. and Wen, R.Z. (2019) Analysis of Wholesome Elements and Heavy Metals in Red Soybean by Inductively Coupled Plasma Mass Spectrometry. American Journal of Analytical Chemistry, 10, 137142.

https://doi.org/10.4236/ajac.2019.104012

Received: March 27, 2019

Accepted: April 14, 2019

Published: April 17, 2019

Copyright $\odot 2019$ by author(s) and Scientific Research Publishing Inc. This work is licensed under the Creative Commons Attribution International License (CC BY 4.0).

http://creativecommons.org/licenses/by/4.0/

\begin{abstract}
Objective: To study wholesome elements and heavy metals in red soybean of Heilongjiang Province. Methods: Samples preparation with hydrodigestion, and twenty-four elements quantitative analysis in red soybean by inductively coupled plasma mass spectrometry technique (ICP-MS) with indium, platinum, ruthenium as internal standard. Results: The red soybean contained many elements necessary to human health, the sequence of elements (higher than $\mathrm{mg} / \mathrm{kg}$ ) was $\mathrm{K}>\mathrm{Mg}>\mathrm{Ca}>\mathrm{Fe} \approx \mathrm{Zn}>\mathrm{Na}>\mathrm{Mn}>\mathrm{Ti}>\mathrm{Cu}>\mathrm{Sr} \approx \mathrm{Ni}>$ $\mathrm{Ba}>$ Mo. Besides the trace elements, the contents of heavy metals were very low than National standard. With reference standard substance and added standard recovery for the quality control of analytical method, the results were credibility, recovery $85 \%-114 \%$, the detect limit $0.2-20 \mathrm{ng} / \mathrm{g}$, linearity range 0 - $200 \mu \mathrm{g} / \mathrm{g}(\mathrm{r}>0.999)$, RSD $(\mathrm{n}=6)<9 \%$. Conclusion: The established method could be applied to the element quantitative analysis in food, simple and high sensitivity.
\end{abstract}

\section{Keywords}

ICP-MS, Red Soybean, Wholesome Elements, Heavy Metals

\section{Introduction}

Red bean has been considered as the world's healthiest food for its pharmacological effects [1] [2]. It contains high protein, fat, vitamin, microelement and thick fibre. Red soybean is rich in microelement such as zinc, copper, magnesium, selenium and phosphorus [3] [4] [5]. Various beneficial trace elements are involved in the normal metabolism and healthy development of human body [6]. In the past, the research on the trace elements of red bean was mostly li- 
mited to several elements, but the research on its total elements contents was rarely reported. In this paper, ICP-MS/AAS was used to determine the content of 24 elements in red bean, providing basic data for scientific use of its medicinal value, development of drugs, food, health products and analysis of local soil and other environmental problems.

\section{Experimental Procedure}

\subsection{Materials and Reagents}

Dried seeds of red bean were collected from Heilongjiang provinces of the Peoples Republic of China (PRC). After collection, the beans were rinsed 3 - 5 times with deionized water and dried in an oven to obtain constant weight. The seeds were then crushed to powder with the help of a Micro plant sample pulverizer (TEST FZ102, Tianjin of China). The powder was sieved using 100 mesh to facilitate digestion.

Multi element mixed standard samples of $\mathrm{Ag}, \mathrm{As}, \mathrm{Ba}, \mathrm{Ca}, \mathrm{Cd}, \mathrm{Co}, \mathrm{Cr}, \mathrm{Cu}, \mathrm{Fe}$, $\mathrm{K}, \mathrm{Mg}, \mathrm{Mn}, \mathrm{Mo}, \mathrm{Na}, \mathrm{Ni}, \mathrm{Pb}, \mathrm{Sb}, \mathrm{Se}, \mathrm{Sn}, \mathrm{Sr}, \mathrm{Ti}, \mathrm{Tl}, \mathrm{V}$ and $\mathrm{Zn}$ were bought from SPEX of USA $(100 \mathrm{mg} / \mathrm{l})$. Internal standards $(10 \mathrm{mg} / \mathrm{l}) \mathrm{In}$, Pt and Ru were also bought from SPEX of USA. Standard of boron $(100 \mathrm{mg} / \mathrm{l})$ was bought from National standard material center. Standard substances of poplar leaves GBW07604 (GSV-3) and tea GBW07605 (GSV-4), nitrate (GR, Jing Rui company of Suzhou), perchloric acid (GR, Shanghai Jinlu Chemical Co. Ltd.), liquid argon $(>99.99 \%)$ and purified water $(>18 \mathrm{M} \Omega$ ) were also used.

\subsection{Instrumentation}

Parameters of Inductively Coupled Plasma Mass Spectrometry (ICP-MS) (X-7, Thermo Electron Corporation of USA): Hoisting speed of sample $1.0 \mathrm{ml} / \mathrm{min}$, atomizer cooling temperature $3^{\circ} \mathrm{C}$, Argon gas pressure 0.6 MPa. The other main parameters of ICP-MS have been presented in Table 1.

Parameters of Avanta atomic absorption spectrophotometer (GBC Co., Austrilia) have been presented in Table 2.

\subsection{Preparation of Samples}

By using an electronic balance (Ohaus AR1140, USA, $\pm 0.0001 \mathrm{~g}$ ) $1.0 \mathrm{~g}$ of red bean sample was accurately weighed. $10 \mathrm{ml}$ of $\mathrm{HNO}_{3}$ was added to it and digested

Table 1. Other prameters of ICP-MS.

\begin{tabular}{cccc}
\hline Item & Parameter & Item & Parameter \\
\hline Forward power & 1200.00 & Analogue Detector & 2260 \\
Cool & 13.00 & PC Detector & 3685 \\
Nebuliser & 0.88 & Focus & 19.60 \\
Auxiliary & 0.75 & Horizontal & 3.00 \\
Sampling Depth & 25.00 & Vertical & 311.00 \\
\hline
\end{tabular}


Table 2. The main parameters of AAS.

\begin{tabular}{ccccc}
\hline Elements & $\begin{array}{c}\text { Wavelength } \\
(\lambda) / \mathrm{nm}\end{array}$ & $\begin{array}{c}\text { Current intensity } \\
(\mathrm{I}) / \mathrm{mA}\end{array}$ & slit/nm & Fuel/1/min \\
\hline $\mathrm{K}$ & 766.5 & 5 & 0.5 & 1.9 \\
$\mathrm{Mg}$ & 285.2 & 4 & 0.5 & 1.6 \\
$\mathrm{Ca}$ & 422.7 & 6 & 0.5 & 2.0 \\
$\mathrm{Fe}$ & 248.3 & 8 & 0.2 & 2.0 \\
$\mathrm{Cu}$ & 324.7 & 3 & 0.5 & 1.8 \\
$\mathrm{Mn}$ & 279.5 & 5 & 0.4 & 1.9 \\
$\mathrm{Na}$ & 589.0 & 6 & 0.5 & 1.6 \\
$\mathrm{Zn}$ & 213.9 & 4 & 0.5 & 2.0 \\
\hline
\end{tabular}

on a temperature controlled electric heating plate (Lab Tech, EG35B). PTEF (polytetrafluoroethylene) was carried out at $120^{\circ} \mathrm{C}$ for $2 \mathrm{~h}$ by adding $10 \mathrm{ml} \mathrm{H}_{2} \mathrm{O}_{2}$, and digesting at $190^{\circ} \mathrm{C}$ continuously (Graphite cover heating digestion instrument, Lab Tech, EHD36 with glass digestion tube).

After digestion $10 \mathrm{ml}$ purified water was added and the liquor changed to yellow or colorless. Heating was continued until a volume of approx. $2 \mathrm{ml}$ reached for removing acids, cooling and setting the volume to $10 \mathrm{ml}$ with purified water for determination.

\subsection{Linearity}

The standard solution of mixed elements with equal concentration was diluted into $0,1,5,10,50,100$ and $200 \mathrm{ug} / \mathrm{L}$ standard series with $1 \%$ nitric acid solution. The internal standard elements In, Pt and Ru were prepared into $20 \mathrm{ug} / \mathrm{L}$. Under the optimized instrument conditions, 22 elements have linear regression over 0.999 in the concentration range of $0-200 \mathrm{ug} / \mathrm{L}$.

\subsection{Recovery and Repeatability}

The recoveries of standard tea were investigated. The standard added samples were treated in parallel with the experimental samples, The results show that the recovery of each element is in the range of $85 \%-114 \%$. Six parallel samples were detected simultaneously, and the RSD was less than $9 \%$. The results are shown in Table 3.

\subsection{Detection Limit}

The blank response values of 24 target elements on ICP-MS were used to determine their detection limits. The detection limit was $0.2-20 \mathrm{ng} / \mathrm{g}$, which indicated that the detection limit met the requirement of accurate quantification of target elements in red beans. The results were shown in Table 3. 
Table 3. Contents of 24 kinds of elements in standard substances and red soybean $(\mathrm{mg} / \mathrm{kg})$.

\begin{tabular}{|c|c|c|c|c|c|c|c|c|}
\hline Isotopes & & $\begin{array}{c}\text { Tea } \\
\text { leaves }\end{array}$ & & $\begin{array}{l}\text { Poplar } \\
\text { leaves }\end{array}$ & Recovery/\% & RSD\% & $\begin{array}{c}\text { Detect } \\
\text { limit }\end{array}$ & $\begin{array}{c}\text { Red } \\
\text { soybean }\end{array}$ \\
\hline${ }^{23} \mathrm{Na}$ & 39.8 & $44 \pm 4$ & 211 & $200 \pm 10$ & 90.5 & 8.6 & 20 & 12.5 \\
\hline${ }^{24} \mathrm{Mg}$ & 1684 & $1700 \pm 100$ & 6513 & $6500 \pm 300$ & 99.0 & 8.3 & 20 & 1755 \\
\hline${ }^{39} \mathrm{~K}$ & 16,596 & $16,600 \pm 600$ & 13,916 & $13,800 \pm 400$ & 99.9 & 7.9 & 20 & 13,112 \\
\hline${ }^{44} \mathrm{Ca}$ & 4332 & $4300 \pm 200$ & 18,330 & $18,100 \pm 700$ & 100 & 5.6 & 20 & 415 \\
\hline${ }^{47} \mathrm{Ti}$ & 26.2 & $24 \pm 3$ & 21.2 & $20.4 \pm 1.7$ & 109 & 4.3 & 20 & 8.61 \\
\hline${ }^{52} \mathrm{Cr}$ & 0.83 & $0.80 \pm 0.02$ & 0.55 & $0.55 \pm 0.05$ & 99.7 & 4.0 & 20 & 0.058 \\
\hline${ }^{55} \mathrm{Mn}$ & 1284 & $1240 \pm 40$ & 45.0 & $45 \pm 2$ & 103 & 3.8 & 20 & 11.7 \\
\hline${ }^{56} \mathrm{Fe}$ & 252 & $264 \pm 10$ & 255 & $274 \pm 10$ & 91.6 & 6.1 & 20 & 25.6 \\
\hline${ }^{59} \mathrm{Co}$ & 0.19 & $0.18 \pm 0.02$ & 0.46 & $0.42 \pm 0.02$ & 96.5 & 3.1 & 2 & 0.069 \\
\hline${ }^{60} \mathrm{Ni}$ & 5.03 & $4.6 \pm 0.3$ & 2.01 & $1.9 \pm 0.2$ & 112 & 4.6 & 10 & 3.85 \\
\hline${ }^{65} \mathrm{Cu}$ & 20.3 & $17.3 \pm 1.0$ & 9.66 & $9.3 \pm 0.5$ & 111 & 3.7 & 10 & 5.72 \\
\hline${ }^{66} \mathrm{Zn}$ & 30.8 & $26.3 \pm 0.9$ & 40.0 & $37 \pm 1$ & 114 & 4.6 & 10 & 24.1 \\
\hline${ }^{75} \mathrm{As}$ & 0.24 & $0.28 \pm 0.03$ & 0.32 & $0.37 \pm 0.06$ & 85.7 & 5.4 & 2 & 0.011 \\
\hline${ }^{82} \mathrm{Se}$ & 0.065 & 0.072 & 0.13 & $0.14 \pm 0.01$ & 89.3 & 5.0 & 20 & 0.015 \\
\hline${ }^{88} \mathrm{Sr}$ & 13.5 & $15.2 \pm 0.5$ & 158 & $154 \pm 5$ & 91.8 & 3.0 & 2 & 4.74 \\
\hline${ }^{95} \mathrm{Mo}$ & 0.035 & $0.038 \pm 0.006$ & 0.17 & $0.18 \pm 0.01$ & 92.1 & 2.8 & 2 & 1.68 \\
\hline${ }^{107} \mathrm{Ag}$ & 0.016 & 0.018 & 0.012 & 0.013 & 88.8 & 1.9 & 10 & $<0.004$ \\
\hline${ }^{111} \mathrm{Cd}$ & 0.048 & $0.057 \pm 0.008$ & 0.32 & $0.32 \pm 0.05$ & 90.1 & 2.3 & 2 & 0.0059 \\
\hline${ }^{118} \mathrm{Sn}$ & - & - & - & - & 93.4 & 3.2 & 10 & 0.025 \\
\hline${ }^{121} \mathrm{Sb}$ & 0.051 & $0.056 \pm 0.005$ & 0.044 & $0.045 \pm 0.005$ & 91.1 & 2.9 & 1 & 0.013 \\
\hline${ }^{137} \mathrm{Ba}$ & 59.2 & $58 \pm 3$ & 27.0 & $26 \pm 2$ & 102 & 1.7 & 10 & 2.75 \\
\hline${ }^{51} \mathrm{~V}$ & 0.85 & 0.86 & 0.58 & 0.64 & 98.8 & 4.8 & 20 & 0.019 \\
\hline${ }^{205} \mathrm{Tl}$ & - & - & - & - & 94.9 & 2.1 & 1 & 0.0057 \\
\hline${ }^{208} \mathrm{~Pb}$ & 4.11 & $4.4 \pm 0.2$ & 1.45 & $1.5 \pm 0.2$ & 93.4 & 3.2 & 1 & 0.025 \\
\hline
\end{tabular}

Note: "." in the table indicates that there is no quantitative value.

\section{Discussion}

\subsection{Elemental Analysis Interference}

ICP-MS can detect elements by mass spectrometry after ionization, and there is interference of compound ions with the same mass-charge ratio and other isotopes. Moreover, the presence of nitric acid, phosphoric acid or sulfuric acid can also produce interference ions. Nitric acid is better, so the excess acid should be removed as far as possible after sample digestion. The interference can be reduced by choosing other isotopes of the elements to be measured, using instrument collision pool technology and adjusting the position of sampling cone. The existence of high concentration of $\mathrm{Na}, \mathrm{K}$ and other ionizable elements will 
greatly increase the number of electrons, which will lead to plasma equilibrium transition and matrix interference. The content of $\mathrm{Na}$ and $\mathrm{K}$ in the experimental system is high, so it is necessary to dilute the sample properly.

\subsection{Internal Standard Elements and Selection of Digestion System}

It is easy to cause large systematic error as the matrix of sample solution is complex. Elements In, Pt and $\mathrm{Ru}$ were used as internal standard correction to analyze all samples, and their response values were between $80 \%$ and $90 \%$. This indicated that the interference changes were stable and the data correction was credible. Internal standard can select elements with similar quality which are not contained in the sample. The existence of internal standard elements with large mass in solution can easily lead to errors in correction results. At present, the main pretreatment methods for element determination are wet digestion, microwave digestion and dry ashing. Dry ashing method is complex, time-consuming and has a large loss of elements. However, the wet digestion method is relatively simple and has little loss of elements. Two kinds of devices, electrothermal plate-PTFE cup and graphite electrothermal digestion instrument-glass tube, were compared. The results show that in nitric acid-perchloric acid (3:1) system, the blank of electrothermal plate-PTFE cup digestion is 4 - 5 times lower than that of glass digestion tube. As glass digestion tube has stronger ability to absorb elements than PTFE cup, the recovery rate of elements becomes worse after deducting the blank of experimental data. Therefore, the electrothermal plate-PTFE cup device is the best choice for digestion, and the cup capping can achieve better reflux effect.

\subsection{Trace Elements in Red Bean}

Concentration of 24 elements present in red bean have been presented in Table 3. The results showed red beans contained many beneficial trace elements for human health, the descending order of trace elements in red beans are $\mathrm{K}>\mathrm{Mg}>$ $\mathrm{Ca}>\mathrm{Fe} \approx \mathrm{Zn}>\mathrm{Na}>\mathrm{Mn}>\mathrm{Ti}>\mathrm{Cu}>\mathrm{Sr} \approx \mathrm{Ni}>\mathrm{Ba}>\mathrm{Mo}$, and other elements were all lower than $1.0 \mathrm{mg} / \mathrm{kg}$, especially the contents of heavy metals such as As, $\mathrm{Pb}, \mathrm{Cd}, \mathrm{Cr}$ and Se were very lower than National standard (National Standard of the People's Republic of China 2005).

\section{Conclusion}

The results obtained in the present research shows that red beans contain many beneficial trace elements for human health. Heavy metals such as $\mathrm{As}, \mathrm{Pb}, \mathrm{Cd}, \mathrm{Cr}$ and $\mathrm{Se}$ in red beans are much lower than National standard, which proved that red bean is a safe food. The quality of red beans from Heilongjiang provinces shows that the soil and other environments of Heilongjiang are relatively good and agricultural products were relatively green.

\section{Fund}

This work was financially supported by Hunan Provincial Innovation Founda- 
tion for Postgraduate (CX2018B453) and Central South University of Forestry \& Technology Research Fund Project for the Introduction of Talents (2018YJ040).

\section{Conflicts of Interest}

The authors declare no conflicts of interest regarding the publication of this paper.

\section{References}

[1] Barbosa, J.T.P., Santos, C.M.M., Bispo, L.D.S., Lyra, F.H., David, J.M., Korn, M.D.G.A. and Flores, E.M.M. (2013) Bromine, Chlorine, and Iodine Determination in Soybean and Its Products by ICP-MS after Digestion Using Microwave-Induced Combustion. Food Analytical Methods, 6, 1065-1070.

https://doi.org/10.1007/s12161-012-9511-6

[2] Buttery, R.G., Seifert, R.M. and Ling, L.C. (1975) Characterization of Some Volatile Constituents of Dry Red Beans. Journal of Agricultural \& Food Chemistry, 23, 516-519. https://doi.org/10.1021/jf60199a053

[3] Wei, Z.L., Shen, L. and Rui, Y.K. (2008) Application of ICP-MS to the Detection of 22 Elements in Transgenic Soybean Oil. Guang Pu Xue Yu Guang Pu Fen XI, 28, 1398-1399.

[4] Yiuchung, Y., Chan, K., Pingyuk, C., Kwokwai, P. and Wingcheong, S. (2009) Analysis of Non-Fat Soybean Powder for the Mass Fractions of Three Elements: Copper and Zinc by Isotope Dilution ICP-MS and Calcium by ICP-AES. Food Chemistry, 112, 1065-1071. https://doi.org/10.1016/j.foodchem.2008.06.067

[5] Wen, R.Z., Han, Y.N., Rui, Y.Y. and Rui, Y.K. (2015) Metal Contents in Glycine Max (L.) Merr. from Seven Provinces of China. Bangladesh Journal of Botany, 44, 151-154. https://doi.org/10.3329/bjb.v44i1.22740

[6] Khairkar, S.R. and Raut, A.R. (2014) Adsorption Studies for the Removal Heavy Metal by Chitosan-G-Poly (Acrylicacid-Co-Acrylamide) Composite. Science Journal of Analytical Chemistry, 2, 67-70. https://doi.org/10.11648/j.sjac.20140206.12 